\title{
Como a fotografia é abordada na produção científica sobre o turismo no contexto Iberoamericano? Um estudo baseado em análise textual
}

\section{How is photography addressed in the scientific production of tourism in the lbero- American context? A study based on textual analysis}

\author{
Maria Jaqueline Elicher \\ Universidade Federal do Estado do Rio de Janeiro - UNIRIO, Brasil \\ maria.elicher@unirio.br \\ Carla Fraga \\ Universidade Federal do Estado do Rio de Janeiro - UNIRIO, Brasil \\ carla.fraga@unirio.br \\ Camila Moraes \\ Universidade Federal do Estado do Rio de Janeiro - UNIRIO, Brasil \\ camila.moraes@unirio.br
}

\begin{abstract}
Resumo
Com base no Paradigma das Novas Mobilidades (PNM), o objetivo geral do estudo é analisar como a "fotografia" é abordada na produção científica sobre o turismo. A pesquisa é exploratória e descritiva, e foi realizada através de levantamento bibliográfico a partir do descritor "fotografia" como "palavra-chave" no banco de dados do Publicações de Turismo. A partir de um corpus textual composto de 16 resumos, foi possível fazer a análise textual através do software Iramuteq. A localização geográfica das temáticas abordadas nos estudos foi representada a partir do software QGis. Os resultados revelam que esse é um campo emergente com diversas abordagens teóricas e metodológicas, sendo indiscutível que há uma série de mobilidades implicadas. As análises textuais (Análise de Similitude e Nuvem de Palavras) mostram isso através da conexão de palavras: "como" "fotografia" e "turístico".
\end{abstract}

Palavras-chave: Turismo; fotografia; mobilidade; análise textual.

\begin{abstract}
Based on the New Mobilities Paradigm (NMP), the main goal is to analyze how "photography" is addressed in the scientific production of tourism. Descriptive and exploratory research was carried out through a bibliographic research of the descriptor "photography" as keyword, from the database Publicações de Turismo. From a textual corpus composed of 16 abstracts, it is possible to perform a textual analysis using the Iramuteq software. The geographical location of the topics covered was studied by the software QGis. The results reveal that this is an emerging field with several theoretical and methodological approaches, being undeniable that it has a series of implicit mobilities. The textual analysis (Analysis of Similitude and Word Cloud) shows this through the connection of words: "how" "photography" and "tourist".
\end{abstract}

Keywords: Tourism; photographic; mobilities; textual analysis.

Dos Algarves: A Multidisciplinary e-Journal, 39-2021.

ISBN 2182-5580 @ ESGHT - University of the Algarve, Portugal.

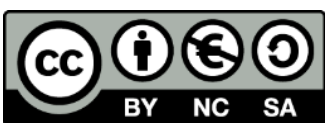

To cite this article: Elicher, M. J., Fraga, C. \& Moraes, C. (2021). Como a fotograia é abordada na produção científica sobre o turismo no contexto Iberoamericano? Um estudo baseado em análise textual Dos Algarves: A Multidisciplinary e-Journal, 39, 52-70. DOI: 10.18089/DAMeJ.2021.39.4 


\section{Introdução}

É inegável que a fotografia esteja diretamente relacionada ao turismo desde o surgimento das primeiras câmeras e dos tours, embora o seu uso enquanto metodologia para a pesquisa ainda seja recente, mesmo considerando o seu crescimento nas últimas décadas. A resistência na aceitação do uso da fotografia, enquanto dado de pesquisa ou documento, em especial para o turismo, se origina certamente na contrariedade das ciências humanas e sociais em aceitá-las como objeto válido de investigação (Kossoy, 2006).

De acordo com Kossoy (2006), nota-se que o emprego da iconografia fotográfica ou outras metodologias com uso de imagem, em trabalhos científicos, se deparam ainda com dificuldades. No que tange ao turismo, vale lembrar que embora o desenvolvimento da fotografia e do turismo moderno estejam fortemente interligados e possam ser considerados contemporâneos, pode-se considerar que houve pouca investigação empírica sobre suas conexões.

No entanto, Martins (2008) defende que a fotografia ao ser abordada como parte ou o todo do método pode apresentar indícios das relações sociais, de mentalidades, de formas de consciência social, de maneiras de ver o mundo e o espaço, de nele viver e de compreendêlo. Assim, concordamos que a fotografia não deve ser descartada como elemento de análise e interpretação da vida cotidiana e dos fenômenos sócio-espaciais. Pois, ao analisarmos esta relação dentro de um debate mais amplo, é possível perceber como as práticas e discursos fotográficos servem para representar o turismo e as viagens e, vice-versa, como as viagens e o turismo estão ligados às práticas fotográficas (Urry \& Crashaw, 2001).

Logo, torna-se relevante discutir na contemporaneidade, a partir do Paradigma das Novas Mobilidades (PNM) de Sheller e Urry (2006), como a "fotografia" é abordada na produção científica sobre o turismo a partir da Análise Textual. Portanto, os objetivos específicos do trabalho são: (a) Analisar a interface entre o turismo e fotografia; (b) avaliar como o PNM pode contribuir para a interpretação dos estudos sobre fotografia e turismo.

É válido destacar que o PNM ainda é um paradigma novo nos estudos do turismo, imagem, etc. Assim justifica-se investigar como as fotografias são abordadas na produção científica sobre turismo, a partir deste Paradigma como um referencial teórico de análise.

Em caráter multidisciplinar, a pesquisa é exploratória e descritiva, sendo que o levantamento bibliográfico sobre o descritor "fotografia" foi realizado a partir de "palavraschave" no banco de dados Publicações de Turismo, disponível no website do Programa de Pós-Graduação em Turismo (PPGTur) da Escola de Artes, Ciências e Humanidades da Universidade de São Paulo (EACH/USP) no dia 03 de abril de 2020. Esse reúne 40 periódicos científicos iberoamericanos de turismo, sendo 11.139 artigos indexados no dia da consulta (Publicações de Turismo, s.d.). A partir do resultado da busca, foi elaborado o corpus textual (composto de 16 resumos), daí foi possível fazer a análise textual através do software Iramuteq, gratuito e com fonte aberta. A localização geográfica das temáticas abordadas nos estudos foi representada a partir do software QGIS, um software livre com código-fonte aberto.

Além da introdução e das considerações finais, esse artigo está subdividido em outras seções, sendo a próxima sobre o aporte teórico conceitual, envolvendo, a interface turismo 
e fotografia e as mobilidades, notadamente o Paradigma das Novas Mobilidades. Já a terceira seção apresenta a metodologia adotada para a análise textual, e, a quarta secção apresenta e discute os resultados encontrados.

\section{Turismo, fotografia e mobilidades}

O turismo, caracterizado como um fenômeno sócio-espacial, embute em si a condição do deslocamento na sua realização e, ao fim, produz um olhar daquele que o realiza sobre o objeto conhecido. Urry (2001: 16) apontou que "o olhar do turista, em qualquer período histórico, é construído em relacionamento com o seu oposto, com formas não-turísticas de experiência e de consciência social: o que faz com que um determinado olhar do turista dependa daquilo com que ele contrasta" Daí que, para o autor, a experiência envolva o conceito de "afastamento", isto é, de ruptura limitada, das práticas rotineiras e cotidianas dos turistas e a partir da criação de expectativas criadas em relação a um determinado lugar e/ou atrativo. Tais expectativas são construídas e mantidas por uma variedade de práticas não-turísticas (Urry, 2001), dentre elas a fotografia motivada pelo e no deslocamento turístico.

Sobre esta discussão, na sociologia do turismo existem diversas abordagens que buscam compreender como o fenômeno turístico acontece e como os turistas escolhem para onde e para o que olhar. Para Boorstin (1964), por exemplo, o turismo é composto por "pseudoacontecimentos", e o turista buscará olhar para as atrações inventadas que lhe tragam maior prazer, desconsiderando o "mundo real". Ao longo do tempo, as imagens geradas pelos olhares do turista, reforçadas pela mídia, passam a constituir um sistema de ilusões, que se estabelece entre a ocultação e a revelação dos objetos e das experiências, o que é fundamental para a compreensão do imaginário social, e que passam a guiar as escolhas dos demais turistas. Assim, o turista, em sua maioria, estará restrito a um conjunto limitado de lugares (hotéis, atrativos turísticos, praias) aprovados por seu olhar, que, no limite, reflete sua própria imagem.

Nesse sentido, MacCannel (1976) discute que o turista busca, essencialmente, o diferente e as "vidas reais" dos outros e que, para isso, as autenticidades encenadas e as atrações turísticas existem para atender a essa demanda e para preservar os moradores locais. Neste aspecto, a fotografia tem, historicamente, cumprido o papel de produzir imaginários e estimuladores motivacionais para as demandas turísticas. Pois como destacou Kossoy (2001), o grande elo entre a fotografia e o turismo está justamente em não ser o retrato da sociedade, mas sim, sua representação e memória fragmentada, passível de interpretações contínuas.

A massificação da fotografia transformou o mundo facilitando a transmissão de informação ou a forma como são documentados os acontecimentos históricos, a vida cotidiana, as memórias familiares e os hábitos de lazer (Sontag, 2004). É hoje documento e forma de representar o espaço, principalmente para o turismo, já que as fotografias de viajantes ganham espaços midiáticos cada vez maiores, assumindo uma nova função: a de construir ou reforçar imaginários que tendem a influenciar a decisão do turista na escolha de um destino. 
Até os anos 1980 tem-se conhecimento das primeiras sistematizações teóricas gerais sobre a fotografia: Collier (1973), Barthes (1984), Flusser (1984), Dubois (1993) e Schaeffer (1996). No entanto, a fotografia apareceu de forma lenta no turismo. Foi a mecanização, a partir da "evolução gradativa dos experimentos e conhecimentos ópticos, físicos, químicos, filosóficos, pictoriais, eletrônicos" e as pesquisas para o aperfeiçoamento da câmera fotográfica que fizeram da fotografia uma ferramenta de uso popular, compartilhada por todos (Hadlich, 2008: 104-105) e que se popularizou efetivamente com o advento das tecnologias digitais.

A aplicação da fotografia no turismo, como já mencionado, trouxe para mais perto um mundo visível que contrapōe para o público diferenças socioculturais, desvenda lugares, registra eventos dos mais variados e é largamente utilizado como recurso pelo marketing turístico. Associada às mídias digitais modernas, a fotografia passou a ocupar um espaço substancial nas atividades do turismo, seja por quem as planeja, seja por quem as usufrui, mudando significativamente o modo de ver e vivenciar as relaçōes humanas. Miskolci (2011: 13) explica que:

\begin{abstract}
Nas ciências sociais, nossos olhares costumam se voltar para as relações entre as pessoas e delas com a sociedade. Se agora essas relações se iniciam, são expandidas ou mantidas pelo uso de mídias digitais precisamos começar a reconhecer seu papel na experiência de nossos sujeitos tanto em termos sociais quanto subjetivos. Nesse sentido, conhecer a história dessas mídias é um passo esclarecedor e necessário.
\end{abstract}

Hadlich (2008: 107) ratifica essa ideia ao afirmar que a forma automática com que as fotografias são feitas contribui, de maneira significativa, para a rapidez de sua produção:

As fotografias passam a simular uma atualidade. A narrativa visual encontrada na fotografia turística está mais favorável para exprimir uma noção de informação, atualidade e similaridade no relato visual. Esses elementos, num nível instrumental, compõem um fazer fotográfico, em que é preconizado o papel fundamental da fotografia como útil para a informação do turismo.

As formas de registro mudaram até chegar à fotografia contemporânea e, ainda que esta não seja a única forma de registro nos dias atuais, estabelece um diálogo direto com as mídias digitais e sua capacidade de compartilhamento. A imagem compartilhada através da fotografia em mídias digitais é carregada de signos e busca transmitir uma mensagem a quem a recebe, ainda que muitas vezes esta transmissão de informação ocorra de maneira subconsciente tanto para quem envia, quanto para quem recebe.

Como afirma Joly (2007), é sempre importante encarar uma imagem como instrumento de expressão e comunicação, embora tenha-se que considerar que entre o aparato fotográfico e o olhar do fotógrafo, que faz o registro, existe uma série de elementos e operações comuns que favorecem a identificação do olhar dele com o da câmera fotográfica. Há que se considerar também "o universo do turista-observador e o tipo de leitura que ele endereça à imagem fotográfica. Toda leitura de imagem é produção de um ponto de vista: 0 sujeito-observador, não o da "objetividade" da imagem" (Hadlich,2008: 108). 
Nessa perspectiva, o registro fotográfico apresenta o relato visual a partir de um ponto de vista: do sujeito que realiza o ato de fotografar. Num plano elementar, é possível considerar que, ao compartilhar o seu registro, o sujeito leva consigo as impressões, olhares e sentimentos a respeito do objeto fotografado e gera um movimento de troca, de fluxos de informações e formas de ver o mundo, o que pode se caracterizar como uma transmissão de valor plástico, informativo e funcional, pois é possível assinalar que a fotografia mostra, revela, expõe, documenta, registra, arquiva, ou seja, dá informação e ajuda a credibilizar o relato visual relacionado ao turismo. A fotografia contribui na geração de mobilidades.

$\mathrm{Na}$ virada do milênio, assistimos a uma intensificação de fluxos globais demandando, assim, uma nova forma de se pensar as sociedades. Uma série de melhorias em meios de transporte, o surgimento de companhias aéreas de baixo custo, bem como os avanços em novas tecnologias de informação e comunicação, tornaram uma parcela do globo mais móvel e mudaram as relações sociais. Diante disso, o sociólogo John Urry passa a defender as mobilidades como um importante objeto de pesquisa e lente de análise, tendo em vista que se apresentam como fenômenos sociais complexos que se dividem em cinco categorias de análise: as mobilidades físicas / corporais de pessoas; as mobilidades de objetos; as mobilidades imaginativas; as mobilidades virtuais e as mobilidades comunicativas (Urry, 2000; Urry, 2007; Moraes, 2017).

Na introdução à coletânea Tourism mobilities: Places to play places in play, Sheller e Urry (2004) analisam o turismo sob as lentes das mobilidades, o que chamam de mobilidades turísticas. Para isso, avaliam como a compressão tempo - espaço, resultado de inovações e ampliação de acesso a diferentes meios de transporte, com novas tecnologias de informação e comunicação, trouxeram as pessoas em todo o mundo para mais perto umas das outras, aumentando os fluxos de viajantes, migrantes e turistas que se deslocam de um lugar para o outro, produzem novos lugares turísticos e novas relações entre turistas e lugares (Sheller \& Urry, 2004 apud Moraes, 2017).

Esse aumento nas mobilidades turísticas, ou das mobilidades físicas / corporais de turistas, gera, por consequência, um aumento nas demais categorias de mobilidades, já que estas, conforme apontado por Urry (2007), fazem parte de um imbricado sistema de mobilidades e, portanto, se inter-relacionam. Deste modo, quanto mais mobilidades turísticas $^{1}$ ou mobilidades de corpos de turistas, mais teremos mobilidades de objetos, imaginativas, virtuais e de comunicação (Moraes, 2017). Ao analisarmos as fotografias no universo do turismo ou das mobilidades turísticas, percebemos que estas também se intensificaram com os avanços nas novas tecnologias de informação e comunicação. A quantidade de fotos tiradas hoje é muito maior do que há 20 anos. Aplicativos foram desenvolvidos para organizar, editar e publicar essa quantidade enorme de fotografias produzidas nos dias de hoje e essa nova forma de se relacionar com a fotografia perpassará uma nova forma de se relacionar com os lugares, como veremos nos resultados. Neste sentido, considerando todas essas complexidades contemporâneas em curso e o futuro do

\footnotetext{
${ }^{1}$ É importante destacar que pensar mobilidades é também pensar imobilidades; a intensificação de imobilidades também gera intensificação de desigualdades nos movimentos virtuais, comunicativos, imagéticos, de objetos e corpos (Moraes, 2017).
} 
turismo, este artigo explora, como a "fotografia" se move na produção científica sobre o turismo. A seguir é apresentada a metodologia adotada no estudo.

\section{Metodologia}

A pesquisa é exploratória e descritiva sendo realizada através de levantamento de dados bibliográficos. No presente trabalho, a busca que originou o resultado que ora se apresenta se deu no banco de dados de Publicações de Turismo, ${ }^{2}$ que reunia, na data da consulta (03 de abril de 2020), 40 periódicos iberoamericanos que utilizam o sistema Open Journal Systems (OJS), sendo 11.139 artigos indexados. Foram encontrados 18 resultados com a busca pela palavra-chave "fotografia". Destes, dois não se aplicavam, pois fugiam à interface turismo e fotografia. Assim, o estudo foi elaborado considerando $n=16$ (ver Quadro 1). É relevante destacar que na busca optou-se por usar apenas "fotografia" como palavra-chave, pois trata-se de um banco de dados sobre turismo, não se justificando a junção dos termos "fotografia e turismo".

Quadro 1. Codificação $(n=16)$

\begin{tabular}{|c|c|c|c|c|c|c|}
\hline Cod. & Título & $\begin{array}{l}\text { Palavras- } \\
\text { chave }\end{array}$ & Autor (ano) & Geo & $\begin{array}{l}\text { Aspectos da } \\
\text { metodologia }\end{array}$ & Periódico \\
\hline$* * * * *$ fot_01 & $\begin{array}{l}\text { Fotografias da } \\
\text { "cidade do Sol": } \\
\text { Um registro de } \\
\text { revelações e } \\
\text { ocultações }\end{array}$ & $\begin{array}{c}\text { Fotografia; } \\
\text { Paisagem; } \\
\text { Turismo; } \\
\text { Natal }\end{array}$ & $\begin{array}{c}\text { Silva \& Alves } \\
\quad(2014)\end{array}$ & $\begin{array}{l}\text { Natal (Rio } \\
\text { Grande do } \\
\text { Norte - } \\
\text { RN), Brasil }\end{array}$ & $\begin{array}{l}\text { Observação } \\
\text { iconográfica e } \\
\text { iconológica }\end{array}$ & $\begin{array}{c}\text { Revista } \\
\text { Brasileira de } \\
\text { Pesquisa em } \\
\text { Turismo }\end{array}$ \\
\hline$* * * * *$ fot_02 & $\begin{array}{c}\text { Fotografias de } \\
\text { viagens: } \\
\text { Replicando } \\
\text { cenas da viagem } \\
\text { perfeita em } \\
\text { Curitiba/PR }\end{array}$ & $\begin{array}{c}\text { Fotografia de } \\
\text { Viagens; Viagem } \\
\text { perfeita; } \\
\text { TripAdvisor; } \\
\text { Curitiba/PR }\end{array}$ & $\begin{array}{c}\text { Ferrari \& } \\
\text { Gândara } \\
\text { (2015) }\end{array}$ & $\begin{array}{l}\text { Curitiba } \\
\text { (Paraná - } \\
\text { PR), Brasil }\end{array}$ & $\begin{array}{l}\text { Semiótica } \\
\text { verbivisual }\end{array}$ & $\begin{array}{c}\text { Caderno } \\
\text { Virtual de } \\
\text { Turismo }\end{array}$ \\
\hline$* * * * *$ fot_03 & $\begin{array}{c}\text { Los orígenes del } \\
\text { turismo cultural } \\
\text { en la Catedral de } \\
\text { Mallorca (1905- } \\
\text { 1936) }\end{array}$ & $\begin{array}{l}\text { Catedral de } \\
\text { Mallorca; turismo } \\
\text { cultural; museu } \\
\text { capitular, guias } \\
\text { turísticos; } \\
\text { fotografias; } \\
\text { século XX* }\end{array}$ & Oliver (2015) & $\begin{array}{l}\text { Catedral } \\
\text { de } \\
\text { Mallorca, } \\
\text { Palmas - } \\
\text { Ilhas } \\
\text { Baleares } \\
\text { (Espanha) }\end{array}$ & $\begin{array}{l}\text { “[...] baseado no } \\
\text { processo de } \\
\text { documentação e na } \\
\text { análise de sua } \\
\text { recepção através } \\
\text { de guias turísticos, } \\
\text { fotografias e a } \\
\text { criação e } \\
\text { desenvolvi- } \\
\text { mento do Museu } \\
\text { Chapterhouse” } \\
\text { (Oliver, 2015: 601)* }\end{array}$ & $\begin{array}{c}\text { Pasos Revista } \\
\text { de Turismo Y } \\
\text { Patrimonio } \\
\text { Cultural }\end{array}$ \\
\hline$* * * * *$ fot 04 & Interpreta-ción & Planejamento & Camacaro \& & Maracaib & Técnica de & Revista \\
\hline
\end{tabular}

\footnotetext{
${ }^{2}$ Publicações de Turismo é um projeto de extensão do Programa de Pós-Graduação em Turismo (PPGTUR) da Escola de Artes, Ciências e Humanidades da Universidade de São Paulo (EACH-USP), elaborado pelo Prof. Dr. Glauber Santos.
} 


\begin{tabular}{|c|c|c|c|c|c|c|}
\hline Cod. & Título & $\begin{array}{l}\text { Palavras- } \\
\text { chave }\end{array}$ & Autor (ano) & Geo & $\begin{array}{l}\text { Aspectos da } \\
\text { metodologia }\end{array}$ & Periódico \\
\hline & $\begin{array}{l}\text { de Fotografías } \\
\text { Aéreas en la } \\
\text { Planificación } \\
\text { Física-Territorial } \\
\text { del Espacio } \\
\text { Turístico }\end{array}$ & $\begin{array}{l}\text { turístico; espaço } \\
\text { turístico; usos do } \\
\text { solo, } \\
\text { interpretação de } \\
\text { fotografias } \\
\text { aéreas* }\end{array}$ & Molina (1999) & $\begin{array}{l}\text { o (Stado } \\
\text { Zulia), } \\
\text { Venezue- } \\
\text { la }\end{array}$ & $\begin{array}{l}\text { Interpretação de } \\
\text { fotografias aéreas }\end{array}$ & $\begin{array}{l}\text { Turismo em } \\
\text { Análise }\end{array}$ \\
\hline$* * * * *$ fot_05 & $\begin{array}{l}\text { Sobre afetos e } \\
\text { fotos: } \\
\text { volunturistas em } \\
\text { uma favela } \\
\text { carioca }\end{array}$ & $\begin{array}{c}\text { Turismo; } \\
\text { Volunturismo; } \\
\text { Afeto; Favela; } \\
\text { Fotografia }\end{array}$ & $\begin{array}{c}\text { Freire- } \\
\text { Medeiros, } \\
\text { Nunes \& } \\
\text { Campello } \\
\text { (2011) }\end{array}$ & $\begin{array}{c}\text { Rio de } \\
\text { Janeiro } \\
\text { (RJ), } \\
\text { Brasil }\end{array}$ & $\begin{array}{c}\text { Observação } \\
\text { participante, } \\
\text { entrevistas em } \\
\text { profundidade, } \\
\text { questionário } \\
\text { semiestruturado e } \\
\text { grupo focal. Acervo } \\
\text { fotoetnográ-fico. }\end{array}$ & $\begin{array}{l}\text { Revista } \\
\text { Brasileira de } \\
\text { Pesquisa em } \\
\text { Turismo }\end{array}$ \\
\hline$* * * * *$ fot_06 & $\begin{array}{c}\text { Turismo e } \\
\text { fotografia: um } \\
\text { estudo } \\
\text { bibliométrico } \\
\text { sobre o uso de } \\
\text { metodologias de } \\
\text { análise da } \\
\text { imagem nas } \\
\text { pesquisas em } \\
\text { turismo }\end{array}$ & $\begin{array}{c}\text { Pesquisa em } \\
\text { turismo; } \\
\text { Metodologias de } \\
\text { análise de } \\
\text { imagem; Novas } \\
\text { metodologias; } \\
\text { Fotografia }\end{array}$ & $\begin{array}{c}\text { Godoy \& } \\
\text { Leite (2019) }\end{array}$ & $\begin{array}{l}\text { Não se } \\
\text { aplica } \\
\text { (Consulta } \\
\text { a Bases de } \\
\text { periódi- } \\
\text { cos } \\
\text { mundiais) }\end{array}$ & $\begin{array}{l}\text { Revisão sistemática } \\
\text { da literatura, sendo } \\
\text { bibliométrico }\end{array}$ & $\begin{array}{l}\text { Revista } \\
\text { Brasileira de } \\
\text { Pesquisa em } \\
\text { Turismo }\end{array}$ \\
\hline$* * * * *$ fot_07 & $\begin{array}{l}\text { Imaginarios } \\
\text { turísticos y } \\
\text { prácticas } \\
\text { fotográficas en } \\
\text { un lugar } \\
\text { histórico y } \\
\text { recreativo en } \\
\text { México }\end{array}$ & $\begin{array}{c}\text { Turismo; } \\
\text { Experiência } \\
\text { Turística; } \\
\text { Imaginários } \\
\text { Sociais; } \\
\text { Fotografia; } \\
\text { Parque Nacional } \\
\text { Molino de Flores } \\
\text { Nezahalcóyotl, } \\
\text { México. }\end{array}$ & $\begin{array}{c}\text { Espinosa \& } \\
\text { Juárez (2019) }\end{array}$ & $\begin{array}{l}\text { Parque } \\
\text { Nacional } \\
\text { Molino de } \\
\text { Flores } \\
\text { (Nezahual } \\
\text { cóyotl), } \\
\text { Cidade do } \\
\text { México, } \\
\text { México }\end{array}$ & $\begin{array}{l}\text { Abordagem } \\
\text { empírica; } \\
\text { qualitativa, } \\
\text { utilizando o } \\
\text { método } \\
\text { etnográfico e o } \\
\text { fenomenoló-gico }\end{array}$ & $\begin{array}{l}\text { Rosa dos } \\
\text { Ventos }\end{array}$ \\
\hline$* * * * *$ fot_08 & $\begin{array}{c}\text { A imagem da } \\
\text { cidade em } \\
\text { fotografias } \\
\text { online: Estudo } \\
\text { de caso do site } \\
\text { Flickr sobre } \\
\text { Curitiba (Paraná, } \\
\text { Brasil) }\end{array}$ & $\begin{array}{c}\text { Turismo; } \\
\text { Marketing; } \\
\text { Imagem; } \\
\text { Fotografia; Flickr; } \\
\text { Curitiba - PR. }\end{array}$ & $\begin{array}{c}\text { Manosso, } \\
\text { Bizinelli \& } \\
\text { Gândara } \\
(2013)\end{array}$ & $\begin{array}{l}\text { Curitiba } \\
\text { (PR), } \\
\text { Brasil }\end{array}$ & $\begin{array}{c}\text { Pesquisa } \\
\text { bibliográfica e } \\
\text { documental. } \\
\text { Categorias de } \\
\text { Análise - Donaire e } \\
\text { Galí (2011). }\end{array}$ & $\begin{array}{l}\text { Turismo \& } \\
\text { Sociedade }\end{array}$ \\
\hline$* * * * *$ fot_09 & $\begin{array}{l}\text { O modelo } \\
\text { semiótico de } \\
\text { análise e leitura } \\
\text { sensorial de } \\
\text { fotografia } \\
\text { turística }\end{array}$ & $\begin{array}{c}\text { Semiótica do } \\
\text { turismo; Modelo } \\
\text { de análise; Leitura } \\
\text { sensorial; } \\
\text { Fotografia } \\
\text { turística }\end{array}$ & Mello (2015) & Diversos & $\begin{array}{l}\text { Modelo Semiótico } \\
\text { Mello (2013) com } \\
\text { aplicação em mini- } \\
\text { análises diversas. } \\
\text { Semiotização } \\
\text { (interpreta-ção) } \\
\text { das imagens } \\
\text { fotográficas } \\
\text { turísticas }\end{array}$ & $\begin{array}{l}\text { Revista } \\
\text { Hospitali- } \\
\text { dade }\end{array}$ \\
\hline
\end{tabular}




\begin{tabular}{|c|c|c|c|c|c|c|}
\hline Cod. & Título & $\begin{array}{l}\text { Palavras- } \\
\text { chave }\end{array}$ & Autor (ano) & Geo & $\begin{array}{l}\text { Aspectos da } \\
\text { metodologia }\end{array}$ & Periódico \\
\hline$* * * * *$ fot_10 & $\begin{array}{l}\text { Representa-ções } \\
\text { sociais do } \\
\text { espaço urbano } \\
\text { turístico de } \\
\text { Ilhéus, Bahia } \\
\text { (Brasil), na } \\
\text { perspectiva do } \\
\text { residente }\end{array}$ & $\begin{array}{l}\text { Espaço urbano; } \\
\text { Turismo; } \\
\text { Representação } \\
\text { social; Fotografia; } \\
\text { Ilhéus. }\end{array}$ & $\begin{array}{c}\text { Alves, Castro } \\
\text { \& Bomfim } \\
(2011)\end{array}$ & $\begin{array}{l}\text { Ilhéus } \\
\text { (Bahia - } \\
\text { BA), Brasil }\end{array}$ & $\begin{array}{c}\text { Teoria das } \\
\text { Representa-ções } \\
\text { Sociais de } \\
\text { Moscovici (2003). } \\
\text { Divisões dos } \\
\text { elementos do } \\
\text { espaço urbano } \\
\text { turístico de Boullón } \\
\text { (2002). }\end{array}$ & $\begin{array}{l}\text { Turismo \& } \\
\text { Sociedade }\end{array}$ \\
\hline$* * * * *$ fot_11 & $\begin{array}{c}\text { O exótico e a } \\
\text { viagem perfeita } \\
\text { na figurativiza- } \\
\text { ção fotográfica } \\
\text { do destino } \\
\text { turístico Curitiba } \\
\text { - Brasil }\end{array}$ & $\begin{array}{c}\text { Exótico; Viagem } \\
\text { Perfeita; } \\
\text { Figurativiza-ção; } \\
\text { Fotografia; } \\
\text { Curitiba-Brasil; } \\
\text { Semiótica }\end{array}$ & $\begin{array}{c}\text { Mello \& } \\
\text { Gândara } \\
\text { (2019) }\end{array}$ & $\begin{array}{l}\text { Curitiba } \\
\text { (PR), } \\
\text { Brasil }\end{array}$ & $\begin{array}{c}\text { Semiótica } \\
\text { discursiva e plástica } \\
\text { (Greimasiana) } \\
\text { ampliada pela } \\
\text { semiótica visual }\end{array}$ & $\begin{array}{l}\text { Pasos - } \\
\text { Revista } \\
\text { Turismo Y } \\
\text { Patrimonio } \\
\text { Cultural }\end{array}$ \\
\hline$* * * * *$ fot_12 & $\begin{array}{l}10 X 15 . \text { Las } \\
\text { tarjetas postales } \\
\text { como huellas de } \\
\text { las prácticas de } \\
\text { los turistas }\end{array}$ & $\begin{array}{c}\text { Postal; Turismo; } \\
\text { Imagens; Cultural } \\
\text { visual; } \\
\text { Fotografia* }\end{array}$ & $\begin{array}{c}\text { Lois \& } \\
\text { Troncoso } \\
(2017)\end{array}$ & Diversos & $\begin{array}{l}\text { Revisão histórica } \\
\text { do cartão postal } \\
\text { como objeto (seus } \\
\text { modos de uso, } \\
\text { formatos e } \\
\text { usuários). Análise } \\
\text { qualitativa dos } \\
\text { cartões postais. }\end{array}$ & $\begin{array}{l}\text { Pasos - } \\
\text { Revista } \\
\text { Turismo Y } \\
\text { Patrimonio } \\
\text { Cultural }\end{array}$ \\
\hline$* * * * *$ fot_13 & $\begin{array}{l}\text { A sociedade do } \\
\text { espetáculo e o } \\
\text { ato de } \\
\text { fotografar nas } \\
\text { viagens }\end{array}$ & $\begin{array}{l}\text { Fotografia; } \\
\text { Turismo; } \\
\text { Consumo; } \\
\text { Espetáculo; } \\
\text { Redes sociais } \\
\text { virtuais }\end{array}$ & $\begin{array}{c}\text { Oliveira \& } \\
\text { Frossard } \\
(2017)\end{array}$ & $\begin{array}{l}\text { Não se } \\
\text { aplica }\end{array}$ & $\begin{array}{l}\text { Exploratória, } \\
\text { qualitativa. } \\
\text { Pesquisa } \\
\text { bibliográfica e } \\
\text { entrevistas em } \\
\text { profundidade. }\end{array}$ & $\begin{array}{l}\text { Pasos - } \\
\text { Revista } \\
\text { Turismo Y } \\
\text { Patrimonio } \\
\text { Cultural }\end{array}$ \\
\hline$* * * * *$ fot_14 & $\begin{array}{l}\text { A relação } \\
\text { turismo e } \\
\text { imagem na } \\
\text { gastronomia } \\
\text { paraense }\end{array}$ & $\begin{array}{l}\text { Fotografia; } \\
\text { Turismo; } \\
\text { Gastronomia; } \\
\text { Belém /Pará }\end{array}$ & $\begin{array}{c}\text { Mareco \& } \\
\text { Simonian } \\
(2019)\end{array}$ & $\begin{array}{c}\text { Belém } \\
\text { (Pará - } \\
\text { PA), Brasil }\end{array}$ & $\begin{array}{c}\text { Referências } \\
\text { bibliográficas. } \\
\text { Pesquisa de campo } \\
\text { de caráter } \\
\text { qualitativo e } \\
\text { quantitativo. }\end{array}$ & $\begin{array}{l}\text { Pasos - } \\
\text { Revista } \\
\text { Turismo Y } \\
\text { Patrimonio } \\
\text { Cultural }\end{array}$ \\
\hline$* * * * *$ fot_15 & $\begin{array}{c}\text { In defense of } \\
\text { tourist } \\
\text { photography }\end{array}$ & $\begin{array}{l}\text { Fotografia; } \\
\text { Turismo; Ética e } \\
\text { Filosofia }\end{array}$ & Haller (2014) & $\begin{array}{l}\text { Não se } \\
\text { aplica }\end{array}$ & $\begin{array}{l}\text { Duas categorias de } \\
\text { análise. }\end{array}$ & $\begin{array}{c}\text { Revista } \\
\text { Turismo \& } \\
\text { Desenvolvi- } \\
\text { mento }\end{array}$ \\
\hline$* * * * *$ fot 16 & $\begin{array}{c}\text { O espaço } \\
\text { turístico de } \\
\text { Parnaíba - PI nas } \\
\text { fotografias on- } \\
\text { line: um estudo } \\
\text { na rede social } \\
\text { Instagram }\end{array}$ & $\begin{array}{l}\text { Fotografia; } \\
\text { Hashtag; } \\
\text { Instagram; TICs; } \\
\text { Turismo. }\end{array}$ & $\begin{array}{c}\text { Perinotto, } \\
\text { Alves, Silva \& } \\
\text { Vieira (2020) }\end{array}$ & $\begin{array}{l}\text { Parnaíba } \\
(\mathrm{PI}), \text { Brasil }\end{array}$ & $\begin{array}{c}\text { Método } \\
\text { bibliográfico, e } \\
\text { netnográfica. } \\
\text { Utilizou o software } \\
\text { Keyhole. }\end{array}$ & $\begin{array}{c}\text { Revista } \\
\text { Acadêmica } \\
\text { Observató-rio } \\
\text { de Inovação } \\
\text { do Turismo }\end{array}$ \\
\hline
\end{tabular}

* Tradução própria 
No Quadro 1, que apresenta a codificação (Cod.) do corpus textual e dados tais como título, palavras-chave, autores e periódicos científicos nos quais foram publicados os estudos, também são destacadas as abrangências geográficas da área/objeto de interesse dos estudos, na coluna "Geo", e aspectos da metodologia.

Para o tratamento dos dados utilizou-se o QGis 3.8 Zanzibar para a apresentação das áreas geográficas de interesse dos estudos. Já para as análises textuais foi utilizado o software Iramuteq versão 0.7 alpha 2, Licença GNU/GPL (c) Pierre Ratinaud Laboratório LERASS. Salviati destaca que o uso deste se destina "[...] aos pesquisadores que trabalham com análise qualitativa de conteúdo textual, como entrevistas, documentos, artigos de revistas, jornais, notícias, etc., fontes usadas tradicionalmente em Ciências Humanas e Sociais" (2017: 4). Daí, justifica-se a sua relevância para a análise da produção científica. Um exemplo nos estudos sobre o turismo é o de Silva et al. (2020); esses autores usaram o Iramuteq para análise de conteúdo de um conjunto de dissertações de mestrado do Programa de Pós-Graduação em Turismo da Universidade Federal do Rio Grande do Norte (UFRN), no Brasil, sendo o "corpus (unificado) derivado dos resumos das dissertações" (Silva et al., 2020: 74).

É válido ressaltar que com relação as metodologias dos estudos sobre a interface turismo e fotografia, o resumo 6 de Godoy e Leite (2019) a partir de um estudo bibliométrico, trata sobre a utilização de metodologias de análise da imagem em pesquisas de turismo (nacionais e internacionais, no período compreendido entre os anos de 2012 a 2017). Sendo que nos resultados, as autoras identificaram o uso de metodologias tradicionais (semiótica e análise de conteúdo) e que várias outras metodologias (tais como: volunteer-employed photography, antropologia visual/fotoetnografia, foto elicitação, Zaltman Metaphor Elicitation Technique - ZMET, Iconografia, entre outras) também fazem parte de alguns estudos. As autoras reforçaram que as metodologias de análise da imagem geralmente são combinadas com outros métodos qualitativos, como, por exemplo, entrevistas em profundidade e observação participante. E isto é uma pista importante para se investigar o uso ou possibilidades de uso dos métodos móveis.

A seguir são apresentados e discutidos os resultados na secção 4, que responde ao objetivo deste trabalho: fazer a análise textual da produção sobre a relação entre turismo e fotografia, para o universo do banco de dados do Publicações de Turismo. Além disto, é apresentado o estudo cronológico e geográfico a partir do corpus textual.

\section{Resultados e discussões}

Retomando a fundamentação teórica sobre fotografia e turismo na perspectiva das mobilidades, Kossoy (2006), Martins (2008), Urry e Crawshaw (2001) discutem as práticas e documentos fotográficos como parte aceitável e relevante das pesquisas científicas. Nessa mesma direção, Feitosa (1999) recupera o papel seminal de Darwin, ressaltando que o cientista já no século XIX considera que: "[...] as fotografias [que] contivessem o máximo de informação fatual. São por si só um depoimento sobre o nascimento da aplicação da fotografia à pesquisa científica." (Feitosa, 1999: 266).

Assim, fica evidente no corpus textual analisado que a temática fotografia e turismo tem sido recorrente na pesquisa científica atualmente. Os resultados mostram que a temática é 
abordada em diversos periódicos científicos iberoamericanos. Nos estudados, três deles apresentam frequência maior que um: Revista Turismo \& Sociedade $(n=2)$; Revista Brasileira de Pesquisa em Turismo ( $n=3)$; Pasos - Revista Turismo Y Patrimonio Cultural $(n=5)$ (ver Figura 1):

Figura 1. Publicações em revistas

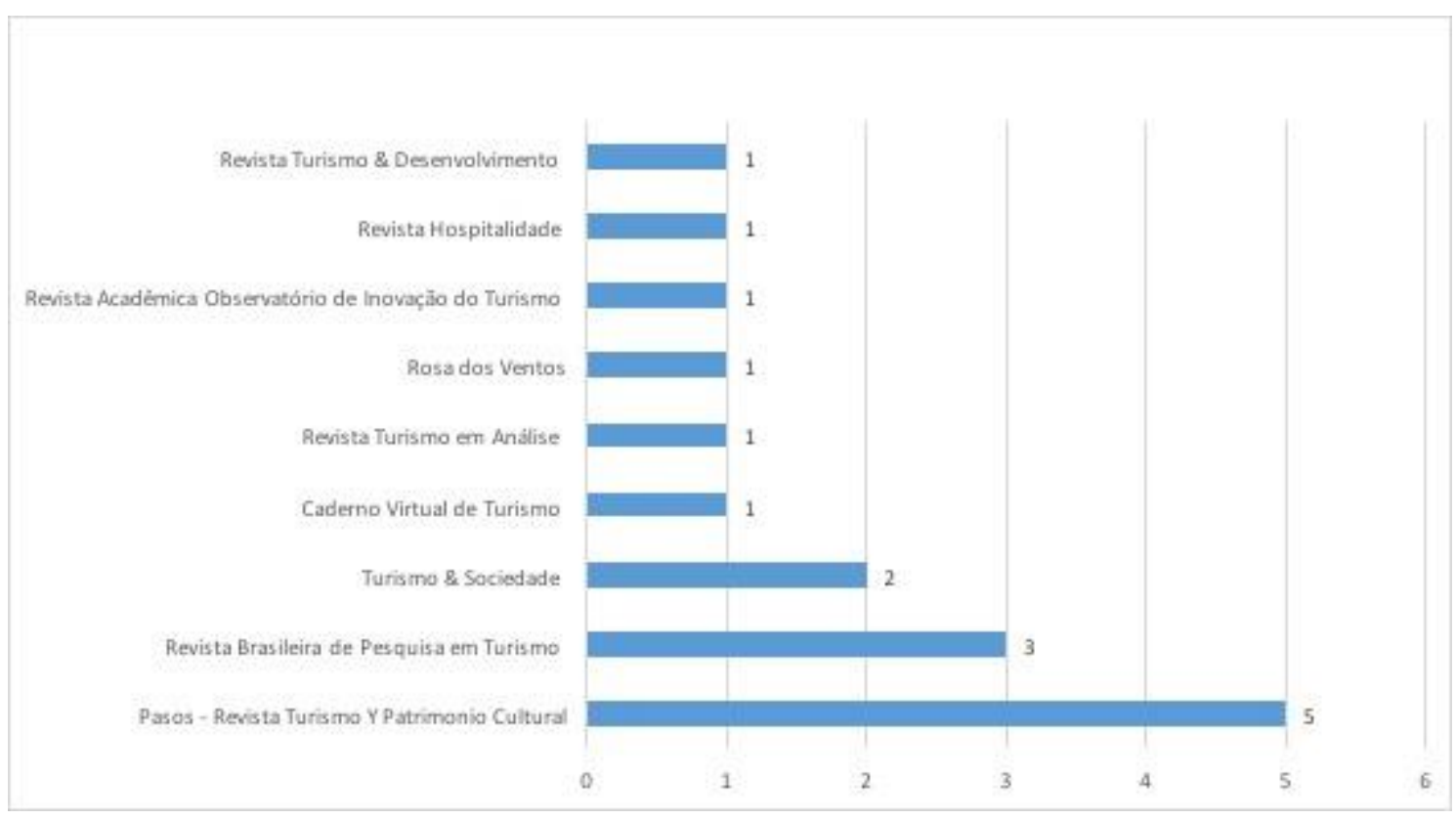

Com relação aos anos de publicação, observa-se a existência de um artigo no final da década de 1990, o de Camacaro e Molina (1999); seguido dos estudos de Freire-Medeiros, Nunes e Campello (2011) e Alves et al. (2011). Daí em diante, observa-se uma constância de publicações (uma ou mais) entre os anos de 2013 e o início de 2020, sendo o ápice em 2019 com a identificação de quatro publicações $(n=4)$ (ver Figura 2), o que demonstra a amplitude da investigação na área na última década e se mostra de acordo com o uso de metodologias de estudo que associam imagens/fotografia e o turismo. É mister indicar (ver Figura 1 e 2) que há uma intensificação na produção ao longo do período analisado, o que corresponde a um aumento das fotografias tiradas por turistas e mais revistas disponíveis on-line. 
Figura 2. Ano publicação

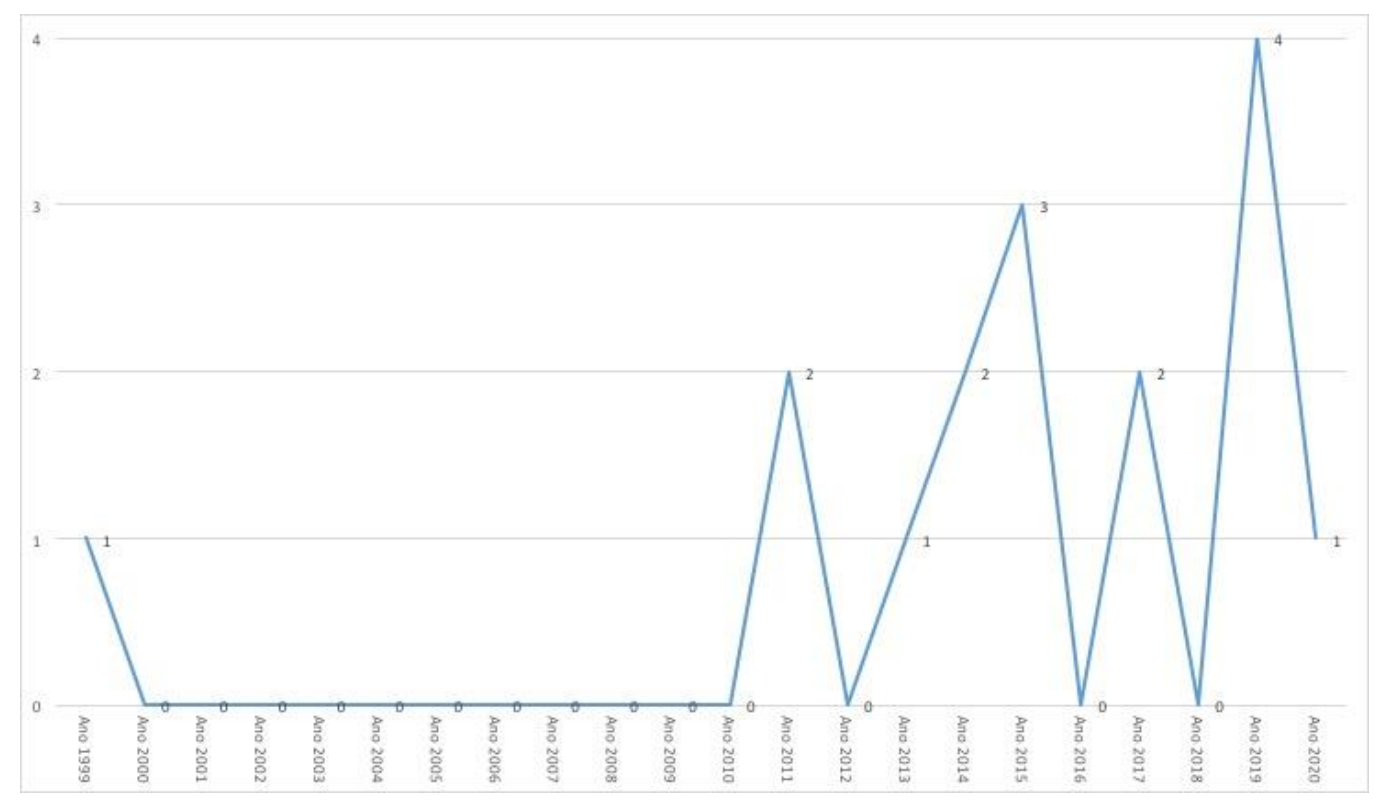

A abordagem geográfica das áreas de interesse dos estudos também foi analisada, sendo que na Figura 3 não foram representados alguns resumos, quais sejam: (a) o de número 6, por se tratar de um estudo bibliométrico; (b) o de número 9, por abordar várias fotografias turísticas não enfocando apenas um dado destino (tais como: Sergipe no Brasil; Baía de Lisboa, em Lisboa, Portugal; Paraty, Rio de Janeiro, Brasil; Taj Majal na Índia; Castelo da Cinderela na Disney, em Orlando, Estados Unidos; Cristo Redentor no Rio de Janeiro, Brasil; Balonismo em Mianmar no Sudeste Asiático; Estações Ferroviárias, Masp em São Paulo, Brasil; Tony Wheeler na África do Sul; Florença na Itália; Bosque de Zanielle em Curitiba, Buenos Aires; Praia no Rio de Janeiro, Brasil; Valle de Luna no Chile e fotos de turistas); (c) o de número 12, por abordar vários cartões postais tais como: Torre Eiffel em Paris; São Luís no Estado do Maranhão, Brasil, Hotel Lhao-Laho y Cerro Viente López (Nahhuel Huapi) Bariloche, Argentina, Rampla Bristol em Mar del Plata - Uruguai, Chesières em Lausanne na Suiça, Nassau nas Bahamas (um sobre aspecto da ilha e outro um hotel da ilha), Tin Hau em Hong Kong, Goiania em Goías no Brasil, Iguaçu no Paraná - Brasil, Disney nos Estados Unidos; (d) o de número 13, por ter tido o foco em "analisar o turismo enquanto bem de consumo na sociedade do espetáculo, refletindo e considerando o ato de fotografar incorporado a este tipo de atividade" (Oliveira \& Frossard, 2017: 261); (e) o de número 15, por se tratar de um debate envolvendo a ética e filosofia na relação entre fotografia e turismo. 
Figura 3. Área geográfica de interesse dos estudos

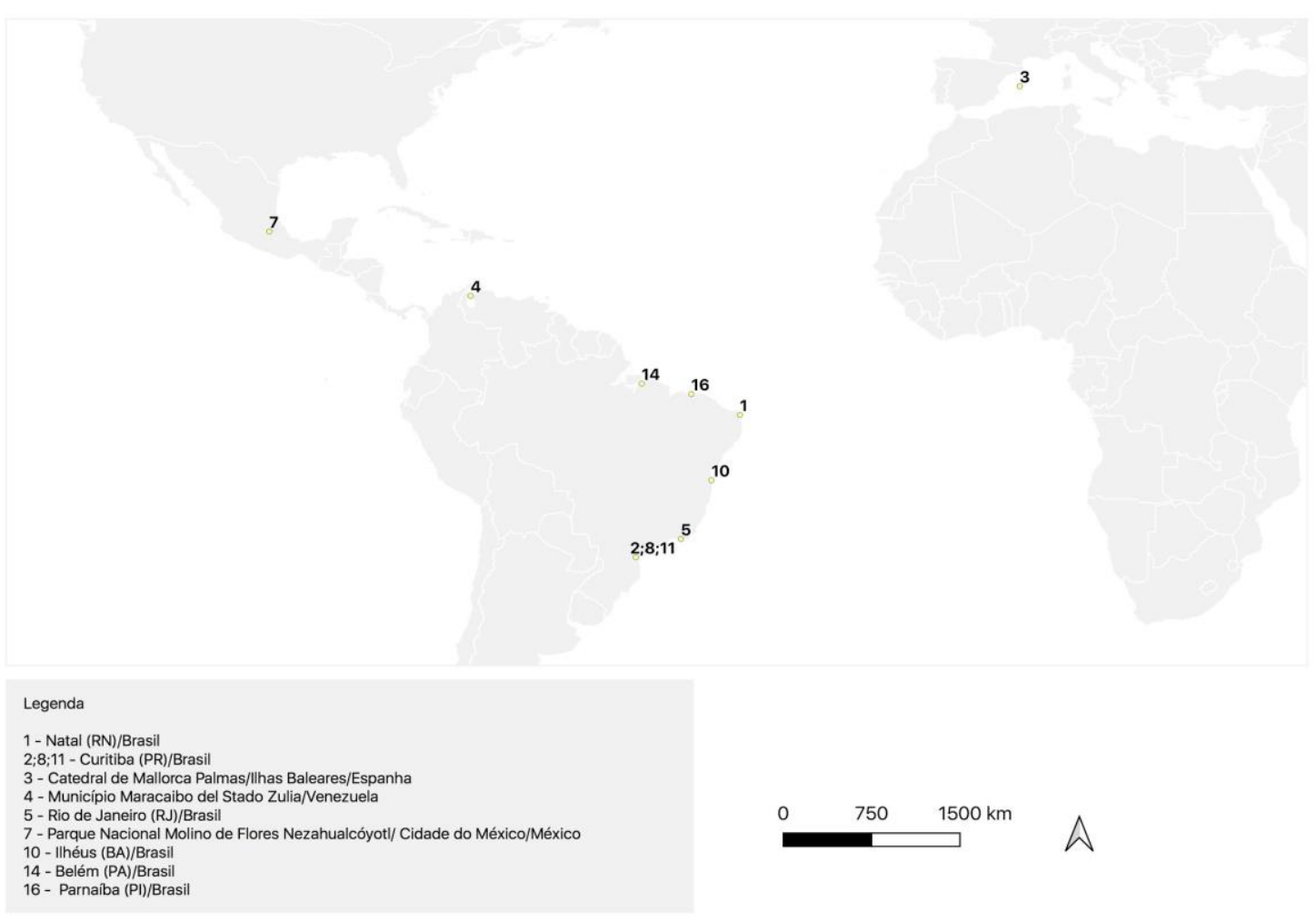

Fonte: Elaborado a partir de QGis 3.8 Zanzibar.

Ainda sobre a Figura 3 observa-se que há uma concentração de estudos nas Américas, o que é coerente por se tratar de uma busca no Publicações de Turismo, que reúne periódicos Iberoamericanos. Em específico, nota-se que a cidade de Curitiba no Paraná, Brasil, é a maior concentração com os resumos 2, 8 e 11, que são respectivamente referentes aos estudos de: Ferrari e Gândara (2015); Manosso, Bizinelli e Gândara (2013) e Mello e Gândara (2019). Fica evidente o interesse do pesquisador Gândara sobre a interface entre turismo e fotografia, assim como a sua atuação em equipes de coautores para tratar a temática. Outra pesquisadora que apresenta autoria de dois trabalhos é Mello, respectivamente em: Mello (2015) e Mello \& Gândara (2019).

A seguir serão apresentados e discutidos os resultados da análise textual empreendidas através do software Iramuteq, notadamente a Análise de Similitude (Figura 4) e a Nuvem de Palavras (Figura 5). Com relação a frequência das palavras, foram consideradas aquelas mais importantes, com frequência igual ou maior que cinco (ver Figura 4 e 5): 
Figura 4. Análise de Similitude

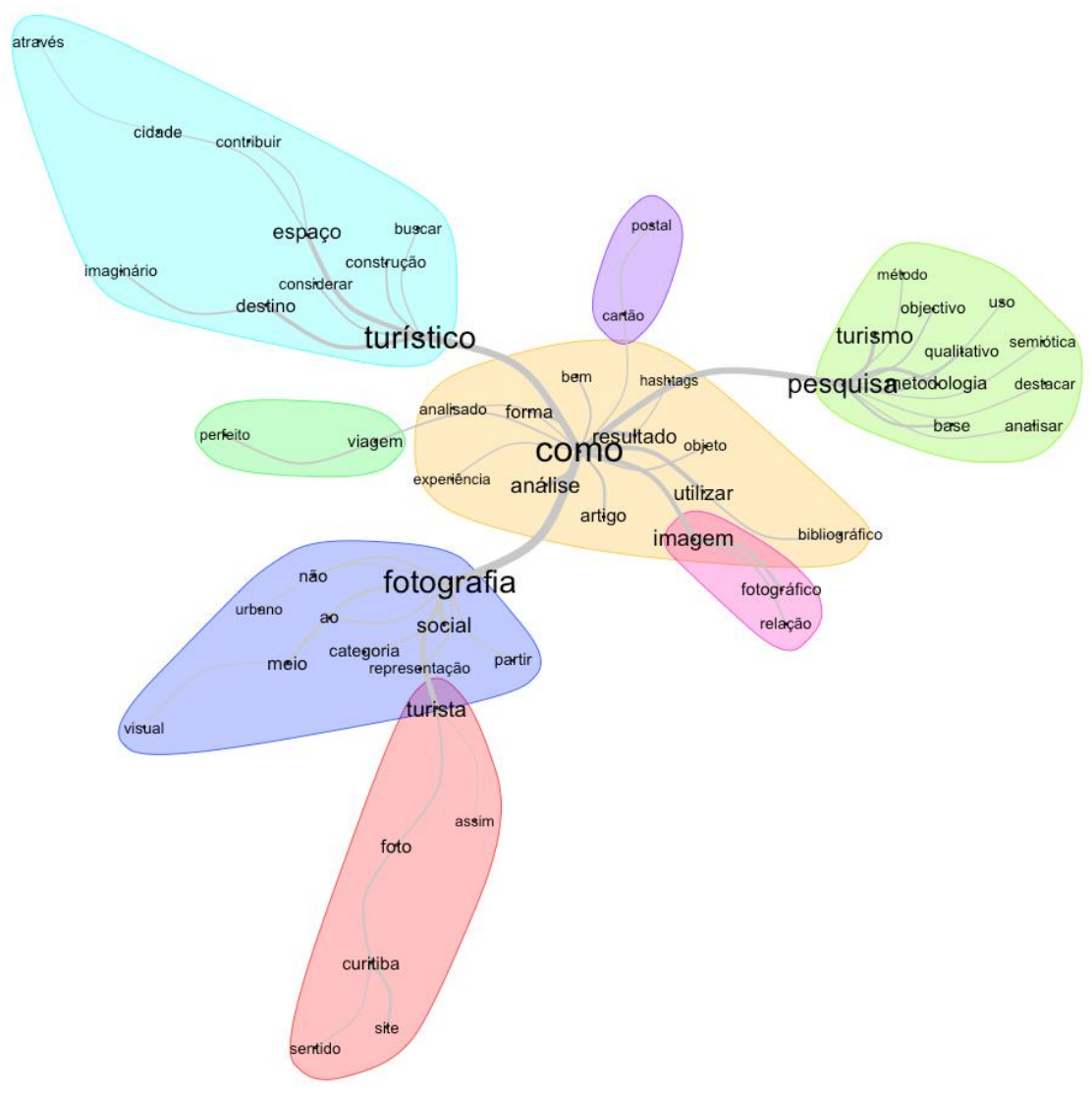

Fonte: Elaborado a partir de Iramuteq 0.7 alpha 2.

Na Análise de Similitude (Figura 4) observa-se a formação de um halo central com a palavra "como" e sua ligação com outros, tendo destaque os halos formados a partir das palavras que aparecem com maior frequência, tais como: "turístico"; "fotografia" e "pesquisa". Nesse sentido, é possível compreender que o "como" é um elo importante que se liga a "fotografia" e ao "turístico", por conta da frequência e da coocorrência dos termos. Nesse sentido, cumpre observar o que Salviati (2017: 69) explica: “A partir desta análise é possível inferir a estrutura de construção do texto e os temas de relativa importância, a partir da coocorrência entre as palavras. Ela auxilia o pesquisador na identificação da estrutura da base de dados (corpus), distinguindo as partes comuns e as especificidades [...].".

Assim, o advérbio "como" é essencial para a compreensão não só da estrutura da base de dados, mas também para a compreensão das especificidades temáticas, por exemplo, a identificação do modo como "fotografia" e "turístico" se relacionam textualmente. Neste sentido, é possível observar que fotografia e turístico se relacionam metodologicamente, tendo em vista que o "como" é um indicativo de método, ou seja, do "como fazer pesquisa".

Nota-se que o halo formado a partir do termo "pesquisa" se justifica pelo fato do corpus ser composto por resumos de trabalhos científicos, daí a ocorrência de palavras como "método", "objetivos", "qualitativo", "semiótica”, "analisar" indicando como a interface tem sido tratada. Os halos menores trazem pistas significativas sobre "cartão" e "postal"; 
"viagem” e "perfeita”, “imagem”, “fotográfico” e "relação”, sendo este um sub-halo do halo central formado pela palavra "como". O halo formado por "turista" tem sua origem no halo sobre "fotografia" perpassando por "representação" e "social". Por outro lado, dentro do halo "turista" há uma ligação direta com a palavra "foto".

A Nuvem de Palavras (Figura 5) corrobora para a centralidade da palavra "como" em relação a outras tais como "turístico", "fotografia" e "pesquisa", ao se relacionar isto com a Figura 2 sobre o ano de publicação é possível afirmar que a interface entre turismo e fotografia é um campo emergente de pesquisa no contexto analisado.

Figura 5. Nuvem de palavras

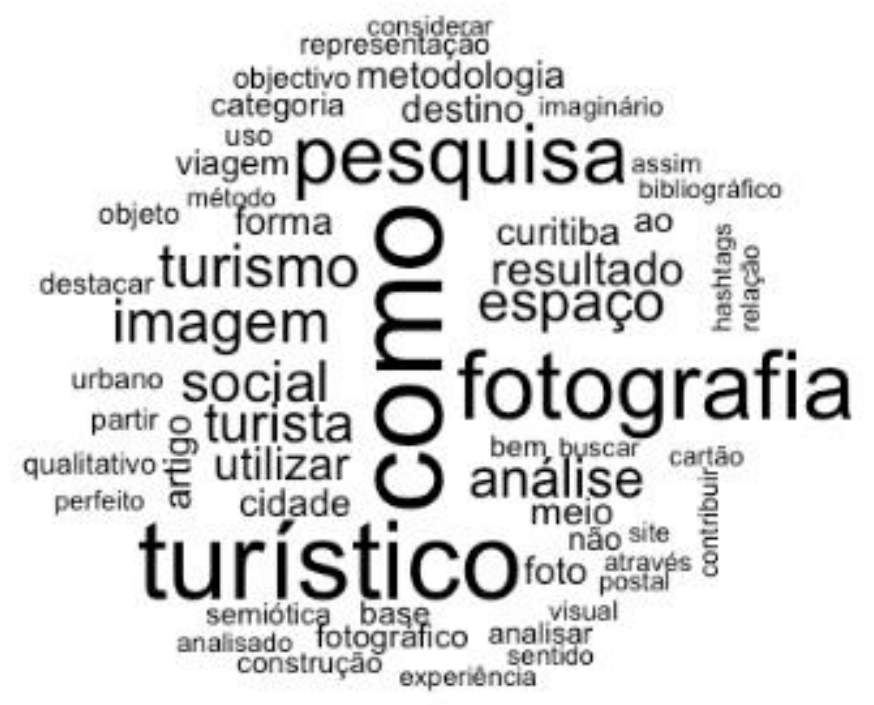

Fonte: Elaborado a partir de Iramuteq 0.7 alpha 2.

Vale salientar que no resumo 1 referente ao trabalho de Silva \& Alves (2014), as imagens (dentre elas a fotográfica) dos destinos turísticos têm sido utilizadas e também consideradas como forma eficaz de atração turística, logo imagem pode ter uma função de movimentar tanto os imaginários quanto as pessoas que se deslocam para fazer turismo. Nesse sentido, a "viagem perfeita" é encontrada nos resumos: 2 (Ferrari \& Gândara, 2015), 11 (Mello \& Gândara, 2019), 13 (Oliveira \& Frossard, 2017), e essa também merece ser investigada quanto a relação entre fotografia e turismo.

É válido destacar que o móvel aqui é a fotografia/imagem do destino. Urry (2007) evidencia como a mobilidade de coisas, fotografias, cartões postais, é mais fácil do que a de pessoas, a mobilidade de pessoas é mais cara, encontra mais barreiras (tais como: nacionalidades, vistos, pandemias) e, nesse sentido, as imagens/fotografias se movem e podem mobilizar pessoas a tornarem-se turistas e se moverem até os lugares. Adicionalmente, cabe explicar que Boden e Molotch, "cujo artigo "The compulsion of 
proximity" (1994) foi formativo das ideias sobre mobilidades, por mostrar o que mobiliza os movimentos, as viagens, o turismo e, na verdade, por que as pessoas sentem necessidades de se encontrar cara a cara, ou de ir até um lugar" (Boden \& Molotch, 1994, apud Moraes, 2016: 238).

Ressalta-se ainda que o papel das fotografias na compreensão das cidades, que são destinos turísticos, busca o que há de específico na contribuição para a construção de paisagens que influenciam o turismo, apresentando elementos ideológicos que motivam sua materialização nos espaços da cidade, como por exemplo, no resumo 1 (Silva \& Alves, 2014). Essa materialização ocorre em função daquilo que se move em função das motivações do que é fotografado, do que é divulgado e do que é consumido, assim "[...] as paisagens da cidade não existem em si mesmas, enquanto um espaço natural, mas foram consolidadas através dos discursos e visualidades [...]." (Silva \& Alves, 2014: 456). Isto dialoga com o que foi colocado por Boorstin (1964) sobre o turismo ser composto por "pseudoacontecimentos", havendo um olhar para atrações inventadas ligadas ao que se move da imaginação (neste caso a partir da fotografia) para o "mundo real".

Outro aspecto presente e que se destaca são os trabalhos que analisam como as fotos dos viajantes/turistas ganham espaços midiáticos e nas redes sociais (via as Novas Tecnologias de Informação e Comunicação) e assumem uma nova função: a da construção de imaginários que tendem a "influenciar" a decisão do turista na escolha de um destino, como exemplo o estudo do resumo 2 de autoria de Ferrari e Gândara (2015). Logo, as mobilidades envolvendo as fotografias também estão imersas nos avanços tecnológicos que permitem a circulação de informações e comunicações diversas, em temporalidades variadas.

Outros usos das fotografias no campo do estudo do fenômeno turístico envolve o uso de tecnologias mais apuradas, como, por exemplo, o de fotografias aéreas, cuja aplicação visa o planejamento do uso do solo urbano para a classificação do espaço turístico, esse é o resumo 4 (Camacaro \& Molina, 1999). Evidente que vinte anos depois da publicação deste estudo houve muitos avanços tecnológicos, com destaque para a tecnologia de drones. Esses também podem ser notados como parte dos métodos móveis (Büscher, Urry \& Witchger, 2010). Conforme apontado por Büscher em entrevista (Moraes, 2016), os drones aparecem como um potencial já explorado em estudos sobre mobilidades. No entanto, ainda são raros (ou inexistentes) os estudos do turismo utilizando drones. Como método, Hildebrand (2020) escreve sobre isso na coletânea Handbook of research methods and applications for mobilities (2020), em seu capítulo sobre "Drone mobilities and autotechnography".

Os resultados encontrados dialogam com o Paradigma das Mobilidades, na medida em que é possível compreender como as fotografias são utilizadas nas pesquisas. Neste sentido, as fotografias de turistas aparecem na produção acadêmica como objetos ou mensagens, dependendo do contexto, a serem seguidos, uma vez que são postados em blogs ou redes sociais durante ou após a viagem, ou seja, se movem virtualmente, ou fisicamente através de cartões postais, tornando-as um interessante objeto de análise para pesquisadores da área. 


\section{Considerações finais}

O turismo enquanto objeto de desejo se nutre invariavelmente de imagens e imaginários, num movimento que envolve cada vez mais as nuances das convergências e divergências entre o real e o virtual. Nesse sentido, a fotografia, bem como os atos de fotografar e de ser fotografado são elementos-chave para o posicionamento de atrações e destinos turísticos no cenário global de viagens. Se a modernidade uniu, com os avanços tecnológicos, imagem e movimento, torna-se relevante discutir na contemporaneidade, a partir do Paradigma das Novas Mobilidades (PNM) de Sheller e Urry (2006), como a "fotografia" é abordada na produção científica sobre o turismo.

Essa abordagem também é válida porque, como mencionado na introdução deste artigo, o PNM ainda é um paradigma novo nos estudos do turismo e imagem. Daí, o presente trabalho contribuir para que os futuros estudos considerem categorias de análise advindos deste, como exemplos: (a) o termo "como" enquanto pista sobre as metodologias utilizadas num contexto disciplinar variado envolvendo a relação entre turismo e fotografia; (b) o termo "imagem" se ligando com outros dois: "fotográfico" e "relação", o que caracteriza, por si só, algum tipo de mobilidade da imagem fotográfica no contexto no estudo das práticas turísticas.

Assim, os resultados revelam que esse é um campo emergente com diversas abordagens teórico-metodológicas, sendo indiscutível que há uma série de mobilidades implicadas, envolvendo principalmente o que fica evidente nas análises textuais (Análise de Similitude e Nuvem de Palavras): "como", "fotografia" e "turístico" se conectam.

Uma limitação do estudo é ter tratado o tema a partir dos resumos, estudos futuros podem se debruçar na análise de textos completos.

Uma agenda futura para pesquisas pode considerar que: (a) na perspectiva metodológica, os estudos anteriores focaram por exemplo em abordagens bibliométricas para conhecer mais sobre essa interface consultando bases de periódicos mundiais, como o de Godoy e Leite (2019). Logo, novos estudos sobre a temática, considerando a análise textual, poderiam focar na busca ampliando bases de busca e identificar como o PNM e os métodos móveis são considerados (ou como poderiam ser considerados); (b) sobre as análises textuais, novos estudos poderiam focar em análises como: Análise Fatorial de Correspondência (AFC), que permite a representação gráfica em um plano cartesiano e a Classificação Hierárquica Descendente pelo Método de Reinert, pois isto permitirá aprofundar sobre categorias de análises para o tratamento da temática; (c) é possível pensar a "viagem perfeita" citada em alguns resumos na perspectiva da utopia, ou melhor, pensar na utopia como método para organização da viagem. Desenvolvida por Levitas (2013), a ideia de utopia como método pode ser um exercício proveitoso em futuros estudos. Isto, pois se configura em uma metodologia hermenêutica relacionada a "iniciativas transformadoras para um mundo melhor", neste caso, para uma viagem melhor (Levitas, 2013, apud Moraes, 2017). 


\section{Referências}

Alves, C. dos R., Castro, L. L. C. \& Bomfim, N. R. B. (2011). Representações sociais do espaço urbano de Ilhéus, Bahia (Brasil), na perspectiva do residente. Turismo \& Sociedade, 4(22), 200-222. doi: 10.5380/tes.v4i2.24759

Barthes, R. (1984). A câmara clara: Nota sobre fotografia (Trad. J. C. Guimarães). Rio Janeiro: Nova Fronteira.

Boden, D. \& Molotch, H. (1994). The compulsion of proximity. In R. Friedland \& D. Boden (Eds.), NowHere: Space, time and modernity (pp. 257-286). California. University of California Press.

Boorstin, D. (1964). The Image: A guide to pseudo-events in America. Nova lorque: Harper and Row.

Büscher, M., Urry, J. \& Witchger, K. (2010). Mobile methods. Londres: Routledge.

Camacaro, L. \& Molina, N. (1999). Interpretación de fotografías aéreas en la planificación físicaterritorial del espacio turístico. Revista Turismo em Análise, 10(2), 78-97. doi: 10.11606/issn.1984-4867.v10i2p78-97

Collier Jr., J. (1973). Antropologia visual: A fotografia como método de pesquisa. São Paulo: EPU.

Dubois, P. (1993). O ato fotográfico e outros ensaios (Trad. M. Appenzeller). Campinas: Papirus.

Espinosa, R. H.; Juárez, M. S. F. (2019) Imaginarios turísticos y prácticas fotográficas en un lugar histórico y recreativo en México. Rosa dos Ventos - Turismo e Hospitalidade, 11(3), 523-543. doi: 10.18226/21789061.v11i3p523

Feitosa, M. A. G. (1999). Resenha: Darwin, o comportamento humano e as emoções. Psicologia: Teoria e Pesquisa, 15(3), 265-267. doi: 10.1590/S0102-37721999000300010

Ferrari, C. M. M. \& Gândara, J. M. (2015). Fotografias de viagens: Replicando cenas da viagem perfeita em Curitiba/PR. Caderno Virtual de Turismo, 15(2), 112-130.

Flusser, V. (1974). Le monde codifié. Paris: Institut de I’Environnement.

Freire-Medeiros, B., Nunes, F. \& Campello, L. (2011). Sobre afetos e fotos: Volunturistas em uma favela carioca. Revista Brasileira de Pesquisa em Turismo, 5(2), 157-176. doi: 10.7784/rbtur.v5i2.424

Godoy, K. E. \& Leite, I. da S. (2019). Turismo e fotografia: Um estudo bibliométrico sobre o uso de metodologias de análise da imagem nas pesquisas em turismo. Revista Brasileira de Pesquisa em Turismo, 13(3), 71-91. doi: 10.7784/rbtur.v13i3.1573

Hadlich, D. (2008). O olhar fotográfico aplicado ao turismo. In L. A. Cândido (Org.), Turismo: Múltiplas abordagens (pp. 105-115). Novo Hamburgo: Feevale.

Haller, S.F. (2014). In defense of tourist photography. Revista Turismo \& Desenvolvimento, 21/22, 413423.

Hildebrand, J. (2020). Drone mobilities and auto-technography. In M. Büscher, M. FreudendalPedersen, S. Kesselring \& N. G. Kristensen (Eds.), Handbook of research methods and applications for mobilities. Elgar (no prelo).

Joly, M. (2007). Introdução à análise da imagem. São Paulo: Papirus.

Kossoy, B. (2001). Fotografia \& história. São Paulo: Ateliê Editorial, Edição revista.

Kossoy, B. (2006). Imagem fotográfica fundamentos teóricos e proposições metodológicas. Boletim: Grupo de Estudos do Centro de Pesquisa de Arte \& Fotografia, 2, 29-36.

Levitas, R. (2013). Utopia as method: The imaginary reconstitution of society. New York: Palgrave MacMillan.

Lois, C. \& Troncoso, C. A. (2017). 10 x 15. Las Tarjetas postales como huellas de las prácticas de los turistas. Pasos: Revista de Turismo y Patrimonio Cultural, 15(3), 633-657. doi: 10.25145/j.pasos.2017.15.043 
MacCannel, D. (1976). The tourist: A new theory of the leisure class. Londres: Macmillan.

Manosso, F. C., Bizinelli, C. \& Gândara, J. M. G. (2013). A imagem da cidade em fotografias online: estudo de caso do site Flickr sobre Curitiba (Paraná, Brasil). Turismo \& Sociedade, 6(4), 835860.

Mareco, C. A. \& Simonian, L. T. L. (2019). A relação turismo e imagem na gastronomia paraense. Pasos: Revista Turismo y Patrimonio Cultural, 17(1), 159-178.

Martins, J. de S. (2008). Sociologia da fotografia e da imagem. São Paulo: Contexto.

Mello, C. M. (2015). O modelo semiótico de análise e leitura sensorial de fotografias turísticas. Revista Hospitalidade, 12(1), 488-514.

Mello, C. M. \& Gândara, J. M. G. (2019). O exótico e a viagem perfeita na figurativização fotográfica do destino turístico Curitiba - Brasil. Pasos: Revista de Turismo y Patrimonio Cultural, 17 (1), 81-96.

Miskolci, R. (2011). Novas conexões: Notas teórico-metodológicas para pesquisas sobre o uso de mídias digitais. Revista Cronos, 12(2), 9-22.

Moraes, C. (2016). Entrevista com Monika Büscher. Trama: Indústria Criativa em Revista. Dossiê: Mobilidades e Cotidianos, 1(1), 235-257.

Moraes, C. M. S. (2017). Favelas ecológicas: Passado, presente e futuro do turismo em favelas (Tese de Doutorado). Rio de Janeiro: Fundação Getulio Vargas/ CPDOC-RJ.

Oliver, M. F. (2015). Los orígenes del turismo cultural en la Catedral de Mallorca (1905-1936). Pasos: Revista de Turismo y Patrimonio Cultural, 13(3), 601-615.

Oliveira, G. C. de; Frossard, M. S. (2017). A sociedade do espetáculo e o ato de fotografar nas viagens. Pasos: Revista de Turismo y Patrimonio Cultural, 15(1), 261-272.

Perinotto, A.R.C.; Alves, C.E.S.; da Silva, L.F. \& Vieira, V.B. (2020). O espaço turístico de Parnaíba-PI nas fotografias on-line: Um estudo na rede social Instagram. Revista Acadêmica Observatório de Inovação do Turismo, 1 (14), 1-22.

$\begin{array}{lllll}\text { Publicações de } & \text { Turismo } & \text { (s.d.) } & \text { Disponível }\end{array}$ http://www.each.usp.br/turismo/publicacoesdeturismo/sobre.php.

Salviati, M. E. (2017) Manual do aplicativo Iramuteq. Planaltina. Disponível em http://www.iramuteq.org/documentation/fichiers/manual-do-aplicativo-iramuteq-par-mariaelisabeth-salviati.

Schaeffer, J. M. (1996). A imagem precária: Sobre o dispositivo fotográfico (Trad. E. Bottman). Campinas: Papirus.

Sheller, M. \& Urry, J. (2004). Tourism mobilities: Places to play, places in play. Nova lorque: Routledge.

Sheller, M. \& Urry, J. (2006). The new mobilities paradigm. Environment and Planning, 38(2), $207-226$. doi: $10.1068 / a 37268$

Silva, A. C. da, Dutra, J. E. M., Lima, L. S. de \& Alexandre, M. L. de O. (2020). Uso e relevância em abordagem quantitativa de pesquisas em Turismo no Programa de Pós-Graduação em Turismo (PPGTUR - UFRN). Revista de Turismo Contemporâneo, 8(1), 65 - 87.

Silva, K. M. S. da \& Alves, M. L. B. (2014). Fotografias da "Cidade do Sol": Um registro de revelações e ocultações. Revista Brasileira de Pesquisa em Turismo, 8(3), 456-475. doi: 10.7784 /rbtur.v8i3.807

Sontag, S. (2004). Sobre fotografia (Trad. R. Figueiredo). São Paulo: Companhia das Letras.

Urry, J. \& Crawshaw, C. (2001). Tourism and the photographic eye. In C. Rojek \& J. Urry (Orgs.), Touring cultures. Transformation of travel and theory (pp. 90-92). Londres: Routledge.

Urry, J. (2000). Sociology beyond societies. Londres e Nova lorque: Routledge. 
Urry, J. (2001). O olhar do turista: Lazer e viagens nas sociedades contemporâneas (Trad. C. E. de Moura). São Paulo: Studio Nobel/SESC.

Urry, J. (2007). Mobilities. Cambridge: Polity.

MARIA JAQUELINE ELICHER é doutora pela Universidade Federal Fluminense, UFF (Niterói/RJ) e mestre em Geografia pela Universidade Federal de Santa Catarina, UFSC (Florianopolis/SC). Professora Adjunta IV do Departamento de Turismo e Patrimônio da Universidade Federal do Estado do Rio de Janeiro UNIRIO. Líder do Grupo de Pesquisa Geografi-Cidades. Membro fundador da Rede de Pesquisa Geografia, Turismo e Literatura (ENTREMEIO). Endereço institucional: Departamento de Turismo e Patrimônio, $\mathrm{CCH}$., Universidade Federal do Estado do Rio de Janeiro, Av. Pasteur, $458 \mathrm{sl}$. 414 . Urca. Rio de Janeiro, CEP: 22.290-240, Brasil.

CARLA FRAGA é doutora e mestre em Engenharia de Transportes pela Universidade Federal do Rio de Janeiro. Bacharel em Turismo e Especialista em Negócios pela Universidade Federal de Juiz de Fora. Cursando Especialização em Neurociência e Psicologia Aplicada pela Universidade Presbiteriana Mackenzie. Professora Associada do Departamento de Turismo e Patrimônio da Universidade Federal do Estado do Rio de Janeiro - UNIRIO. Líder do Grupo de Pesquisa Transportes e Turismo (GPTT). Membro da Rede de Pesquisa Geografia, Turismo e Literatura (ENTREMEIO). Endereço institucional: Departamento de Turismo e Patrimônio, $\mathrm{CCH}$., Universidade Federal do Estado do Rio de Janeiro, Av. Pasteur, 458 sl. 414. Urca. Rio de Janeiro, CEP: 22.290-240, Brasil.

Camila Moraes é professora do Departamento de Turismo e Patrimônio da UNIRIO e coordenadora da TurisData: Base de Dados sobre os Estudos do Turismo e Mobilidades e o Observatório do Turismo em Favelas. Graduada em Turismo (UNIRIO), Especialista em Sociologia Urbana (UERJ), mestre em Ciências Sociais (UERJ) e doutora em História, Política e Bens Culturais (CPDOC / FGV-RJ), com estágio de doutorado no Centro de Pesquisa para Mobilidades da Lancaster University. Docente dos Cursos de Graduação em Turismo e Ciências Sociais e das Pós-Graduações em Memória Social e em Ecoturismo e Conservação. Endereço institucional: Departamento de Turismo e Património, Universidade Federal do Estado do Rio de Janeiro, Av. Pasteur, 458. CCH, sl. 414. Urca. Rio de Janeiro, CEP: 22.290-255, Brasil.

Submetido em 3 de junho de 2020

Aceite em 24 de setembro de 2020 